\title{
Soya protein- and casein-based nutritionally complete diets fed during gestation and lactation differ in effects on characteristics of the metabolic syndrome in male offspring of Wistar rats
}

\author{
Alireza Jahan-mihan, Ignatius M. Y. Szeto, Bohdan L. Luhovyy, Pedro S. P. Huot \\ and G. Harvey Anderson* \\ Department of Nutritional Sciences, Faculty of Medicine, University of Toronto, 150 College Street, Room 322, \\ Toronto, ON, Canada M5S $3 E 2$
}

(Received 29 October 2010 - Revised 6 April 2011 - Accepted 14 April 2011 - First published online 29 June 2011)

\begin{abstract}
The AIN-93G diets based on soya protein or casein were fed to pregnant Wistar rats from day 3 of gestation and compared for their effects on characteristics of the metabolic syndrome in male offspring. Pregnant rats were randomised to either a casein (C) or soya protein (S) diet ( $n$ 12) during gestation only (Expt 1) or during gestation and lactation (Expt 2). Male offspring were weaned to either a $\mathrm{C}$ or $\mathrm{S}$ diet for 9 weeks (Expt 1) or 15 weeks (Expt 2). In Expt 1, pups born to S-fed dams had higher fasting blood glucose (BG), systolic blood pressure (SBP) and diastolic blood pressure (DBP) at week 4, higher blood glucose (BG) response to a glucose administration $(P<0 \cdot 001)$ and higher body weight $(\mathrm{BW})$ at week $8(P<0.05)$. In Expt 2, consumption of the $\mathrm{S}$ diet throughout gestation and lactation resulted in higher $\mathrm{BW}$ $(P<0.05)$, DBP $(P<0.005)$ and SBP $(P<0.005)$ in the offspring. They also had higher homeostasis model assessment of insulin resistance (HOMA-IR; $P<0.05)$ and plasma homocysteine $(P<0.05)$ at weaning, higher fasting BG and glucose response to glucose administration $(P<0.005)$ at week 12 and higher HOMA-IR $(P<0 \cdot 01)$ at week 15 . Although composition of the weaning diets interacted with the diet of the dams, the latter was the dominant factor in determining metabolic outcomes in the offspring. In conclusion, the $S$ diet, compared with the $\mathrm{C}$ diet, when consumed during gestation or throughout gestation and lactation increased the presence of characteristics of the metabolic syndrome in the offspring.
\end{abstract}

Key words: Protein source: Fetal programming: Metabolic syndrome: Blood pressure

Epidemiological, clinical and animal studies have shown that fetal and early postnatal nutrition alters the development of somatic structure, endocrine systems and homeostatic mechanisms in the fetus and infant. These effects influence the risk of developing obesity and components of the metabolic syndrome in later life ${ }^{(1-3)}$.

Both low- and high-protein diets fed during gestation and lactation have adverse effects on the offspring ${ }^{(4-8)}$, but the mechanisms by which they bring about these effects are unclear. Rats born to dams fed a low-protein diet have increased blood pressure $(\mathrm{BP})^{(9)}$, body weight $(\mathrm{BW})^{(8)}$, adiposity $^{(10)}$ and compromised glucose metabolism ${ }^{(11)}$. Similarly, high-protein diets fed during gestation and lactation increase $\operatorname{adiposity}^{(12)}, \mathrm{BW}^{(13)}$, BP, food efficiency ${ }^{(13)}$ and decrease energy expenditure in the offspring ${ }^{(12)}$.
In addition to the requirement for adequate and balanced amounts of essential amino acids for protein synthesis, amino acids have potential to elicit significant effects on development through additional actions ${ }^{(6,14-17)}$. The addition of glycine $e^{(15,17)}$ to low-protein diets ameliorates the effect of the diet on vascular dysfunction and $\mathrm{BP}^{(15)}$, while adding taurine normalises insulin secretion in the offspring ${ }^{(18)}$. Although their mechanism of action remains unexplained, it may include their effects on DNA methylation. Amino acids have the potential to affect DNA methylation during fetal development either directly by involvement in DNA methylation pathways or indirectly through effects on hormonal and oxidative status of maternal blood reaching the fetus ${ }^{(15,16,19,20)}$. Furthermore, because of the effects of individual amino acids on regulatory systems ${ }^{(6,16,18-20)}$, malnutrition may not be the only prerequisite for the effects of proteins and amino acids

\footnotetext{
Abbreviations: BG, blood glucose; BW, body weight; C, casein; DBP, diastolic blood pressure; FPM, fat pad mass; GTT, glucose tolerance test; HOMA-IR, homeostasis model assessment of insulin resistance; ITT, insulin tolerance test; S, soya protein; SBP, systolic blood pressure; tAUC, total incremental area under the curve.
} 
in maternal diets on development of the offspring. Thus, it is possible that protein source and amino acid composition of nutritionally complete maternal diets affect the phenotype of the offspring. Furthermore, whether development of the offspring is affected differently by dietary protein consumed during gestation only or throughout gestation and lactation has not been reported, but would be expected because the development of regulatory systems in rodents continues in late fetal and early postnatal life ${ }^{(19,21)}$.

The primary objective of the present study was to test the hypothesis that nutritionally complete diets ${ }^{(22)}$ differing in protein sources and fed during gestation alone or during gestation and lactation differ in their effects on characteristics of the metabolic syndrome in the offspring. Therefore, Wistar rat dams were fed either the AIN-93G soya protein (S)- or casein (C)-based diet. In addition, because the Predictive Adaptive Response Hypothesis suggests that the effect of the maternal diet on the offspring is reduced if the diet of the offspring is similar to that of the dams, two groups of offspring from both maternal groups were fed either a S- or C-based diet. Therefore, the secondary objective was to determine the effect of protein composition of the weaning diet on the consequences of the dams' diets in the offspring.

\section{Experimental methods}

\section{Animals and diets}

First-time pregnant Wistar rats were received at day 3 of gestation (Charles River, QC, Canada) and were housed individually in ventilated plastic transparent cages with bedding at $22 \pm 1^{\circ} \mathrm{C}$ and a $12 \mathrm{~h} \mathrm{light}-12 \mathrm{~h}$ dark cycle (lights off at 22.00 to 10.00 hours). At weaning, rat offspring were housed individually in ventilated plastic transparent cages with bedding. The powdered diets were provided ad libitum in stainlesssteel cups with a mesh disc insert to reduce spillage. All rats had free access to water throughout the experiments.

The composition of the $\mathrm{C}$ diet was as follows: casein $(200 \cdot 0 \mathrm{~g} / \mathrm{kg})$, maize starch $(529 \cdot 4 \mathrm{~g} / \mathrm{kg})$, sucrose $(100 \cdot 1 \mathrm{~g} / \mathrm{kg})$, soyabean oil $(70.0 \mathrm{~g} / \mathrm{kg})$, cellulose $(50 \cdot 0 \mathrm{~g} / \mathrm{kg})$, vitamin mixture $(10.0 \mathrm{~g} / \mathrm{kg})$, mineral mixture $(35.0 \mathrm{~g} / \mathrm{kg})$, cystine $(3.0 \mathrm{~g} / \mathrm{kg})$, choline bitartarate $(2.5 \mathrm{~g} / \mathrm{kg})$ and tert-butyl hydroquinone $(0 \cdot 014 \mathrm{~g} / \mathrm{kg})$. The composition of the $\mathrm{S}$ diet was identical to the $\mathrm{C}$ diet, except that soya protein replaced casein, and methionine $(2.54 \mathrm{~g} / \mathrm{kg})$ and cystine $(2.54 \mathrm{~g} / \mathrm{kg})$ were added to the $\mathrm{S}$ diet and cystine $(3.0 \mathrm{~g} / \mathrm{kg})$ to the $\mathrm{C}$ diet as recommended for the AIN-93G diets ${ }^{(22)}$. Amino acid content of the $\mathrm{C}$ and $\mathrm{S}$ diets as fed is shown in Table 1. Maize starch, high-protein casein $(87 \%)$ and cellulose were purchased from Harlan Teklad (Madison, WI, USA). The vitamin and mineral mixtures, cystine, methionine, choline bitartrate and tert-butyl hydroquinone were purchased from Dyets, Inc. (Bethlehem, PA, USA), sucrose from Allied Food Service (Toronto, ON, Canada) and soyabean oil from Loblaws (Toronto, ON, Canada).

Genistein, daidzein and glycitein content of the $\mathrm{S}$ diet was $36 \cdot 1,31 \cdot 3$ and $4 \cdot 4 \mu \mathrm{g} / \mathrm{g}$, respectively.
Table 1. Amino acid composition of casein and soya protein AIN-93G diets $(\mathrm{g} / \mathrm{kg} \mathrm{diet})^{*}$

\begin{tabular}{|c|c|c|}
\hline & Miscellar casein† & Isolated soya proteinł \\
\hline Ala & $4 \cdot 7$ & $6 \cdot 7$ \\
\hline Arg & $5 \cdot 7$ & 11.9 \\
\hline$A s p+A s n$ & $10 \cdot 6$ & $18 \cdot 0$ \\
\hline Cys§ & 3.5 & 4.5 \\
\hline $\mathrm{Glu}+\mathrm{Gln}$ & 34.8 & 29.9 \\
\hline Gly & $2 \cdot 8$ & $6 \cdot 7$ \\
\hline His & 4.4 & $4 \cdot 1$ \\
\hline Ile & 8.7 & $7 \cdot 7$ \\
\hline Leu & 13.9 & $12 \cdot 8$ \\
\hline Lys & $12 \cdot 2$ & 9.9 \\
\hline Met\| & 4.0 & 4.5 \\
\hline Phe & $7 \cdot 7$ & $8 \cdot 1$ \\
\hline Pro & $16 \cdot 0$ & 7.9 \\
\hline Ser & 8.4 & $8 \cdot 1$ \\
\hline Thr & $6 \cdot 6$ & 5.9 \\
\hline Trp & 1.7 & $2 \cdot 2$ \\
\hline Tyr & 8.0 & 5.9 \\
\hline Val & $10 \cdot 4$ & 7.9 \\
\hline
\end{tabular}

* The amino acid content of the diets is calculated based on purity of the protein sources ( 87 and $90 \%$ for casein and soya protein, respectively) and the totals include the addition of the free amino acids.

$\dagger$ Harlan Teklad.

$\ddagger$ Dyets, Inc.

$\S$ Cystine was added to both casein ( $3 \mathrm{~g} / \mathrm{kg}$ diet) and soya protein $(2.54 \mathrm{~g} / \mathrm{kg}$ diet $)$ diets.

|| Methionine was added to only the soya protein diet $(2.54 \mathrm{~g} / \mathrm{kg}$ diet $)$.

The protocol was approved by the University of Toronto Animal Care Committee and care and maintenance of the animals conformed to the guidelines of the Canadian Council on Animal Care.

\section{Experimental design}

To examine the main and interactive effects of the dams' and the pups' diets on the offspring, two experiments were conducted with a $2 \times 2$ design. To test the primary hypothesis, the $\mathrm{C}$ and $\mathrm{S}$ diets were fed to the dams only during gestation in Expt 1 and throughout gestation and lactation in Expt 2. To test the Predictive Adaptive Hypothesis, male offspring from both Expt 1 and 2 were fed either a $\mathrm{C}$ or $\mathrm{S}$ diet and were followed for 9 and 15 weeks post-weaning, respectively.

Expt 1: the effect of protein source in the diet fed during gestation and after weaning on components of the metabolic syndrome in male offspring

The objective of the present study was to investigate the effect of the $\mathrm{C}$ or $\mathrm{S}$ diet fed to pregnant dams only during gestation on postnatal development in male offspring fed either a $\mathrm{C}$ or $\mathrm{S}$ diet. Beginning at $3 \mathrm{~d}$ of gestation, two groups of pregnant rats ( $n$ 12) were fed either a C or S diet. During lactation, both groups received only the $\mathrm{C}$ diet. $\mathrm{BW}$ of the offspring was measured at birth (day 1, after litters were culled to 10 pups) and on days 7, 14 and 21. At weaning (day 21 of age), one male offspring from each mother in each diet group was assigned to either the $\mathrm{C}$ or $\mathrm{S}$ diet $(n 12)$. BW was measured weekly for 8 weeks after weaning. Systolic BP (SBP) and diastolic BP (DBP) and pulse rate at week 4 and 
blood glucose (BG) response to a glucose load at week 8 were measured. Fat pad mass (FPM: abdominal + epididymal + perirenal fats) was measured at killing at 9 weeks.

\section{Expt 2: the effect of protein source in diets fed during} gestation and lactation and after weaning on components of the metabolic syndrome in male offspring and in the dams

The objective of the present study was to investigate the effect of feeding the dams the $\mathrm{C}$ and $\mathrm{S}$ diets throughout gestation and lactation, and to extend the duration of observation on the pups fed either the $\mathrm{C}$ or $\mathrm{S}$ diet. During gestation and lactation, two groups of pregnant rats ( $n$ 12) were fed either the $\mathrm{C}$ or $\mathrm{S}$ diet, and were maintained on the same diets for another 6 weeks after weaning. At weaning, one male offspring from each mother in each diet group was assigned to either the $\mathrm{C}$ or $\mathrm{S}$ diet for 15 weeks ( $n$ 12). For the remaining pups, BW was measured at birth (day 1, after litters were culled to 10 pups) and on days 7, 14 and 21. At birth, weaning (day 21 of age) and at week 15 post-weaning, rats (twelve animals per dam diet group) were killed. BW was measured weekly from weaning to week 15 after weaning. Body fat composition was determined at birth, at weaning and at week 15. SBP and DBP were measured at week 2 in the dams, and SBP, DBP and pulse rate at weeks 4,8 and 12 in the pups. Glucose and insulin tolerance tests (ITT) were conducted at weeks 4, 8 and 12.

Trunk blood of fetuses ( $n$ 5-6) obtained at day 20 of gestation in Expt 2 and pups at birth in both experiments was pooled. Pups ( $n$ 12) were killed by decapitation after a $12 \mathrm{~h}$ overnight food deprivation at week 9 in Expt 1, and at weaning and week 15 in Expt 2. Plasma concentrations of insulin, homocysteine, corticosterone, albumin and glucose were measured.

Dams from Expt 2 on the S or C diet were killed at days 14 and 20 of gestation $(n 6)$ and at week 6 after weaning $(n 12)$. Glucose tolerance tests (GTT) were conducted at 3 weeks post-weaning. Plasma concentrations of glucose, insulin, corticosterone, homocysteine and albumin were measured.

\section{Glucose tolerance test}

Rats were fasted overnight for $10 \mathrm{~h}$. A blood sample was withdrawn from the tail vein before and at 15, 30 and $60 \mathrm{~min}$ after a glucose administration $(0.375 \mathrm{~g}$ glucose $/ \mathrm{ml}$, $5 \mathrm{~g}$ glucose/kg BW).

\section{Insulin tolerance test}

Rats were fasted overnight for $10 \mathrm{~h}$. Insulin (Humulin ${ }^{\circledR}$-R; Eli Lilly and Company, Indianapolis, IN, USA) injections were given intraperitoneally $(0.5 \mathrm{U} / \mathrm{ml}, 0.75 \mathrm{U}$ insulin $/ \mathrm{kg} \mathrm{BW})$ and blood was obtained before and at 15, 30 and $60 \mathrm{~min}$ after an insulin injection.

\section{Blood pressure}

SBP and DBP were measured by the non-invasive tail-cuff method with optical plethysmography using a tail manometertachometer system (BP-2000, Visitech system; Apex, NC, USA). Rats were restrained in holders on a platform with constant temperature of $30^{\circ} \mathrm{C}$. They were adapted daily to the device for $5 \mathrm{~d}$. On the day of measurement, five mock measurements preceded a series of ten measurements and only the latter were used in calculating the average as reported previously $^{(23)}$.

\section{Blood glucose}

Tail vein glucose concentration was assayed using a hand-held commercial glucose meter (MediSense Precision Xtra; Abbott Laboratories, Alameda, CA, USA) using test strips ${ }^{(23)}$. Glucose in plasma from trunk blood obtained upon decapitation was measured using a glucose oxidase kit (Ascensia Elite XL; Bayer AG, Leverkusen, Germany).

\section{Blood collection}

Trunk blood was collected in chilled vacutainer tubes (BD, Franklin Lakes, NJ, USA) containing EDTA + Trasylol® (Bayer AG, Leverkusen, Germany) solution (10\% blood volume, $\left.5 \times 10^{8} \mathrm{Iu} / \mathrm{l}\right)$. Blood samples were centrifuged for $20 \mathrm{~min}$ at $3000 \mathrm{~g}$ and $4^{\circ} \mathrm{C}$ for $10 \mathrm{~min}$. Plasma was separated and immediately stored at $-80^{\circ} \mathrm{C}$.

\section{Hormone assays}

Plasma insulin was measured using Insulin Enzyme Immunoassay (Cat no. 80-INSRT-E01; Alpco Diagnostics, Salem, $\mathrm{NH}$, USA) with an assay sensitivity of $0 \cdot 124 \mathrm{ng} / \mathrm{ml}$. Plasma homocysteine was measured by Enzyme Immunoassay (Cat. no. 194-5361; Bio-Rad Laboratories, Inc., Hercules, CA, USA) with a sensitivity of $1.0 \mu \mathrm{mol} / \mathrm{l}$. Plasma albumin was measured using a colorimetric assay (Cat. no. 11970909; Roche Diagnostics, Indianapolis, IN, USA) with a sensitivity of $2.0 \mathrm{~g} / \mathrm{l}$. Plasma corticosterone was measured using Enzyme Immunoassay (Cat. no. DSL-10-81 100; Beckman Coulter, Webster, TX, USA) with an assay sensitivity of $1.6 \mathrm{ng} / \mathrm{ml}$.

\section{Body composition}

Fat mass and lean mass were measured at birth by dual-energy X-ray absorptiometry (pSabre; Orthometrix, Naples, FL, USA) applying a specialised software program (Host Software version 3.9.4; Scanner Software version 1.2.0) ${ }^{(24)}$. After killing, carcasses were placed directly on the dual-energy X-ray absorptiometry. All scans were performed at a speed of $10 \mathrm{~mm} / \mathrm{s}$ and a resolution of $0.5 \times 1.0 \mathrm{~mm}$. At weaning and at the end of the experiments, FPM was measured by dissection of extracted abdominal, epididymal and perirenal fat. 


\section{Isoflavone measurement}

Homogenised soya protein samples were analysed for isoflavones (genistein, daidzein and glycitein) by GC-MS, as described previously ${ }^{(25)}$. The isoflavone analysis involved extraction of samples twice with $5 \mathrm{ml}$ of $70 \%$ methanol, passing a portion of extraction through a C18 solid-phase extraction column (SPE column; Octadecyl C18/14\%, $200 \mathrm{mg} / 3 \mathrm{ml}$; Applied Separations, Allentown, PA, USA), hydrolysis with $\beta$-glucuronidase (Helix Pomatia; Sigma-Aldrich, St Louis, MO, USA) and passage through another C18 SPE column. An internal standard ( $5 \alpha$-androstane- $3 \beta, 17 \beta$-diol; Steraloids, Inc., Wilton, NH, USA) was added to the column eluent, and the sample was then derivatised with Tri-Sil Reagent (Pierce Company, Rockford, IL, USA) before injection to the GC-MS (Agilent 6890 series GC system interfaced with an Agilent 5973 network mass selective detector; Agilent Technologies, Wilmington, DE, USA).

\section{Statistical analyses}

All data are expressed as means with their standard errors. BG response was calculated as the total incremental area under the curve (tAUC) of the BG concentration over $1 \mathrm{~h}$ after receiving glucose administered for the GTT and after receiving insulin injection for the ITT. For the former, the reported tAUC is positive above baseline, whereas for the latter, the tAUC is a negative representing the area below baseline. The homeostasis model assessment of insulin resistance (HOMA-IR) index was calculated as fasting glucose multiplied by fasting insulin divided by $22 \cdot 5^{(26)}$. All analyses were conducted using SAS (version 9e; SAS Institute, Cary, NC, USA). The effect of the two diets fed to the dams, the two diets fed to the pups and the interactions between the dams' and pups' diets on BW, glucose response, SBP and DBP was analysed by two-way ANOVA. When repeated measures were made over time on $\mathrm{BW}$ and $\mathrm{BG}$, the PROC MIXED MODEL procedure was used with dams' diets, pups' diets and time as main factors. A one-way ANOVA followed by post hoc Tukey's test was conducted to compare treatment effects when interactions were statistically significant. Student's unpaired $t$ test was applied to mean comparisons of effects of the maternal diets on plasma measures. Statistical significance was defined at $P<0 \cdot 05$.

\section{Results}

Expt 1: the effect of protein source in the diet fed during gestation and after weaning on components of the metabolic syndrome in male offspring

Gestational diet did not affect birth weight (6.2 (SEM 0.2) v. $6 \cdot 3$ (SEM $0 \cdot 1) \mathrm{g}$ ) in rats born to dams fed the $\mathrm{C}$ and $\mathrm{S}$ diets, respectively. However, at week 9, BW of offspring born to the S dietfed dams was $5 \%$ higher (450.3 (SEM 5.7) $v .427 \cdot 3$ (SEM 5.3) g, $P<0.05$; Fig. 1$)$. At week 4 , SBP was $18 \%(P<0.05)$, DBP was $7 \%(P<0.05)$ and pulse rate was $6 \%$ higher $(P<0.01)$ in pups born to dams fed the $S$ diet (Table 2). At week 9, fasting BG was $8.5 \%$ higher in rats born to the $\mathrm{S}$ diet-fed dams $(P<0.05$; Table 3$)$. However, the gestational diet did not affect glucose response to glucose administration in the offspring at week 8 (Table 4) or FPM (15.6 (SEM 0.7) and 15.2 (sem 0.7) g, C and S diets, respectively) at week 9.

The pup diet influenced glucose metabolism. At week 8, the tAUC for glucose after the glucose administration was higher in rats weaned to the $\mathrm{S}$ diet $(P<0.001$; Table 4). At week 9 , higher fasting BG $(14 \%, P<0.01)$, insulin $(11 \%, P<0.005)$, and HOMA-IR index $(45 \%, P<0.001)$ were found in rats weaned to the $S$ diet (Table 3 ) but, as indicated, by an interaction $(P=0.06)$ between the gestational diets and weaning diets, the effect of the weaning diet was stronger in those born to dams fed the $\mathrm{S}$ diet.

\section{Expt 2: the effect of protein source in diets fed during} gestation and lactation and after weaning on components of the metabolic syndrome in male offspring and in the dams

Offspring. There were no differences ( $\mathrm{C} v$. S diets, respectively) due to the protein source in the dams' diets on the

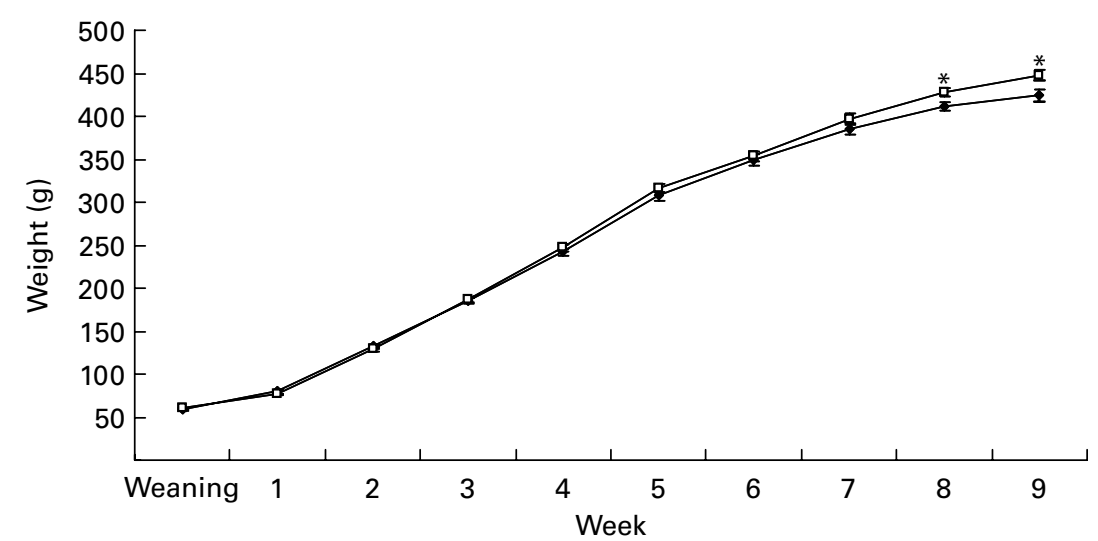

Fig. 1. Expt 1: effect of protein source during gestation on post-weaning body weight (BW) of male offspring. Values are means, with their standard errors represented by vertical bars ( $n$ 12). BW was analysed by MIXED model followed by Tukey's post hoc test with gestational diet, weaning diet and time as main factors: gestational diet (NS); weaning diet (NS); time $(P<0.0001)$; gestational diet $\times$ time $(P<0.005)$. ${ }^{*}$ Mean values were significantly different $(P<0.05)$. Data are pooled for the pup diet to present the effect of gestational diet alone on BW. C, casein $(-\downarrow-)$; S, soya protein $(-\square-)$. 
Table 2. Effect of protein source in diets of dams and offspring on systolic blood pressure (SBP) and diastolic blood pressure (DBP) and pulse rate* (Mean values with their standard errors, $n 11-12$ )

\begin{tabular}{|c|c|c|c|c|c|c|c|c|c|c|}
\hline \multirow{3}{*}{$\begin{array}{l}\text { D... } \\
\text { W... }\end{array}$} & \multirow[b]{3}{*}{ Week } & \multicolumn{4}{|c|}{$\mathrm{C}$} & \multicolumn{4}{|c|}{$\mathrm{S}$} & \multirow[b]{3}{*}{$P$} \\
\hline & & \multicolumn{2}{|c|}{$\mathrm{C}$} & \multicolumn{2}{|c|}{$\mathrm{S}$} & \multicolumn{2}{|c|}{$\mathrm{C}$} & \multicolumn{2}{|c|}{$\mathrm{S}$} & \\
\hline & & Mean & SEM & Mean & SEM & Mean & SEM & Mean & SEM & \\
\hline \multicolumn{11}{|c|}{$\mathrm{SBP}(\mathrm{mmHg})$} \\
\hline & 4 & 128 & $2 \cdot 2$ & 130 & 3.5 & 137 & $10 \cdot 9$ & 134 & $3 \cdot 9$ & $\begin{array}{l}\mathrm{D}: P<0.05 \\
\mathrm{~W}: \mathrm{NS}\end{array}$ \\
\hline \multicolumn{11}{|c|}{ Expt 2 (gestation and lactation diet) } \\
\hline & 4 & $120^{a, b}$ & $3 \cdot 8$ & $110^{\mathrm{a}}$ & $5 \cdot 8$ & $119^{a, b}$ & $5 \cdot 9$ & $132^{b}$ & $7 \cdot 0$ & $\mathrm{D}: P<0.005$ \\
\hline & 8 & $130^{a, b}$ & 4.9 & $113^{\mathrm{a}}$ & $5 \cdot 5$ & $127^{a, b}$ & $5 \cdot 0$ & $136^{\mathrm{b}}$ & $5 \cdot 6$ & W: NS \\
\hline & 12 & $119^{a, b}$ & $5 \cdot 9$ & $103^{a}$ & $10 \cdot 3$ & $142^{b}$ & $10 \cdot 6$ & $131^{a, b}$ & $9 \cdot 4$ & $\begin{array}{l}\mathrm{D} \times \mathrm{W}: P<0.01 \\
\mathrm{~T}: \mathrm{NS}\end{array}$ \\
\hline \multicolumn{11}{|c|}{$\mathrm{DBP}(\mathrm{mmHg})$} \\
\hline & 4 & 93 & $4 \cdot 8$ & 100 & $3 \cdot 2$ & 110 & $5 \cdot 4$ & 104 & $5 \cdot 6$ & $\begin{array}{l}\mathrm{D}: P<0.05 \\
\mathrm{~W}: \mathrm{NS} \\
\mathrm{D} \times \mathrm{W}: P<0.01\end{array}$ \\
\hline \multicolumn{11}{|c|}{ Expt 2 (gestation and lactation diet) } \\
\hline & 4 & 99 & 3.9 & 95 & $8 \cdot 1$ & 100 & 4.9 & 111 & $7 \cdot 6$ & $\mathrm{D}: P<0.005$ \\
\hline & 8 & 105 & $6 \cdot 1$ & 90 & $7 \cdot 3$ & 106 & $6 \cdot 6$ & 118 & $7 \cdot 6$ & W: NS \\
\hline & 12 & 82 & 8.9 & 89 & $13 \cdot 6$ & 107.9 & $9 \cdot 4$ & 115 & $10 \cdot 0$ & T: NS \\
\hline \multicolumn{11}{|c|}{ Pulse (BPM) } \\
\hline \multicolumn{11}{|c|}{ Expt 1 (gestational diet) } \\
\hline & 4 & 417 & $7 \cdot 3$ & 426 & $11 \cdot 9$ & 447 & $6 \cdot 1$ & 445 & $9 \cdot 3$ & $\begin{array}{l}D: P<0.001 \\
W: N S\end{array}$ \\
\hline \multicolumn{11}{|c|}{ Expt 2 (gestation and lactation diet) } \\
\hline & 4 & 388 & $4 \cdot 6$ & 387 & $9 \cdot 3$ & 408 & $10 \cdot 3$ & 399 & $8 \cdot 7$ & $\mathrm{D}: P<0.05$ \\
\hline & 8 & 382 & $6 \cdot 7$ & 357 & $12 \cdot 4$ & 397 & $10 \cdot 8$ & 394 & $9 \cdot 6$ & $\mathrm{~T}: P<0.05$ \\
\hline & 12 & 379 & $6 \cdot 4$ & 378 & $5 \cdot 6$ & 384 & $7 \cdot 6$ & 378 & $9 \cdot 1$ & W: NS \\
\hline
\end{tabular}

D, dams' diet; C, casein; S, soya protein; W, weaning diet; T, time; BPM, beats per minute.

${ }^{a, b}$ Mean values within a row with unlike superscript letters were significantly different $(P<0.05)$.

${ }^{*}$ MIXED model with D and W (Expt 1) and D, W and T (Expt 2) as main factors followed by Tukey's post hoc test when interaction was significant.

pups at birth in litter size (13.2 (SEM 0.7) and $13 \cdot 2$ (SEM 0.5)), male:female ratio $(0.53$ (SEM 0.05$)$ and 0.52 (SEM 0.03)), body fat $(0.3$ (SEM 0.04) and 0.4 (SEM 0.05) g) or BW (6.2 (SEM 0.2) and $6 \cdot 3(\operatorname{sem} 0 \cdot 1) \mathrm{g})$ and at weaning in BW $(62 \cdot 2$ (SEM $2 \cdot 1)$ and $56 \cdot 3($ SEM 3.2) g) and FPM (0.5 (SEM 0.1) and 0.4 (sem $0 \cdot 1) \mathrm{g}$ ). However, at week 15 , BW of offspring was higher by $9 \%(615.5$ (SEM 8.2) v. 564.8 (SEM 8.8) g, $P<0.05)$ if born to $\mathrm{S} v$. C diet-fed dams (Fig. 2). Their abdominal fat $(22 \cdot 0$

Table 3. Effect of protein source in diets of dams and offspring on fasting plasma measures in the offspring*

(Mean values with their standard errors, $n 5-6$ )

\begin{tabular}{|c|c|c|c|c|c|c|c|c|c|c|}
\hline \multirow{3}{*}{$\begin{array}{l}\text { D... } \\
\text { W... }\end{array}$} & \multicolumn{4}{|c|}{ C } & \multicolumn{4}{|c|}{$S$} & & \\
\hline & \multicolumn{2}{|c|}{ C } & \multicolumn{2}{|c|}{$S$} & \multicolumn{2}{|c|}{$\mathrm{C}$} & \multicolumn{2}{|c|}{ S } & \multicolumn{2}{|c|}{$P$} \\
\hline & Mean & SEM & Mean & SEM & Mean & SEM & Mean & SEM & D & $W$ \\
\hline \multicolumn{11}{|l|}{ Week 9 post-weaning } \\
\hline \multicolumn{11}{|l|}{ Expt 1 (gestational diet) } \\
\hline Glucose (mм) & $5 \cdot 6$ & 0.3 & $6 \cdot 1$ & 0.3 & 5.8 & 0.4 & 6.9 & 0.2 & 0.05 & 0.01 \\
\hline Insulin (ng/ml) & 0.67 & 0.20 & 1.03 & 0.08 & 0.49 & $0 \cdot 10$ & 1.40 & $0 \cdot 18$ & NS & 0.005 \\
\hline HOMA-IR ${ }^{\dagger}$ & $0 \cdot 16$ & 0.50 & 0.28 & 0.02 & 0.13 & 0.04 & 0.43 & 0.06 & NS & 0.001 \\
\hline Corticosterone $(\mathrm{ng} / \mathrm{ml})$ & $249 \cdot 1$ & 11.4 & $255 \cdot 8$ & 11.6 & $229 \cdot 3$ & $9 \cdot 8$ & $236 \cdot 8$ & 8.0 & NS & NS \\
\hline Homocysteine $(\mu \mathrm{mol} / \mathrm{l})$ & $3 \cdot 1$ & $0 \cdot 1$ & 3.5 & 0.7 & 3.7 & 0.7 & 3.9 & 0.4 & NS & NS \\
\hline \multicolumn{11}{|l|}{ Week 14 post-weaning } \\
\hline \multicolumn{11}{|c|}{ Expt 2 (gestational and lactation diet) } \\
\hline Glucose (mм) & $5 \cdot 0$ & 0.2 & $5 \cdot 2$ & 0.2 & 5.5 & 0.2 & $5 \cdot 8$ & 0.2 & 0.005 & NS \\
\hline Insulin (ng/ml) & 1.92 & 0.30 & $2 \cdot 25$ & 0.07 & $2 \cdot 33$ & 0.22 & $2 \cdot 20$ & $0 \cdot 15$ & NS & NS \\
\hline HOMA-IR & 0.43 & $0 \cdot 10$ & 0.50 & 0.03 & 0.57 & 0.05 & 0.58 & 0.03 & 0.01 & NS \\
\hline Corticosterone (ng/ml) & $330 \cdot 0$ & $19 \cdot 6$ & $315 \cdot 6$ & $14 \cdot 3$ & 331.2 & 37.9 & $318 \cdot 6$ & $9 \cdot 0$ & NS & NS \\
\hline Homocysteine $(\mu \mathrm{mol} / \mathrm{l})$ & $8 \cdot 8$ & 0.6 & 8.4 & $1 \cdot 1$ & 9.4 & 1.2 & $9 \cdot 0$ & 0.6 & NS & NS \\
\hline
\end{tabular}

D, dams' diet; C, casein; S, soya protein; W, weaning diet; HOMA-IR, homeostasis model assessment of insulin resistance.

${ }^{*}$ MIXED model with $\mathrm{D}$ and $\mathrm{W}$ diets as main factors. Expt 1: interaction for HOMA-IR $(P=0.06)$.

† HOMA-IR index was calculated as fasting glucose $(\mathrm{mM})$ multiplied by fasting insulin $(\mathrm{ng} / \mathrm{ml})$ divided by 22.5 . 
Table 4. Effect of protein source in diets of dams and offspring on blood glucose response during the oral glucose and insulin tolerance tests ${ }^{*}$ (Mean values with their standard errors, $n 10-12$ )

\begin{tabular}{|c|c|c|c|c|c|c|c|c|c|c|}
\hline \multirow{3}{*}{$\begin{array}{l}\text { D... } \\
\text { W... }\end{array}$} & \multirow[b]{3}{*}{ Week } & \multicolumn{4}{|c|}{ C } & \multicolumn{4}{|c|}{$S$} & \multirow[b]{3}{*}{$P$} \\
\hline & & \multicolumn{2}{|c|}{ C } & \multicolumn{2}{|c|}{$\mathrm{S}$} & \multicolumn{2}{|c|}{$\mathrm{C}$} & \multicolumn{2}{|c|}{$\mathrm{s}$} & \\
\hline & & Mean & SEM & Mean & SEM & Mean & SEM & Mean & SEM & \\
\hline \multicolumn{11}{|c|}{$\begin{array}{l}\text { GTT }(\min \times \text { mmol/ll)† } \\
\text { Expt } 1 \text { (gestational diet) }\end{array}$} \\
\hline & 8 & 486 & $5 \cdot 8$ & 554 & $22 \cdot 7$ & 494 & $18 \cdot 2$ & 541 & $16 \cdot 0$ & $\begin{array}{l}\text { D: NS } \\
W: P<0.001\end{array}$ \\
\hline \multicolumn{11}{|c|}{ Expt 2 (gestation and lactation diet) } \\
\hline & 4 & 514 & $16 \cdot 8$ & 497 & $9 \cdot 3$ & 517 & $11 \cdot 8$ & 496 & $12 \cdot 0$ & $\mathrm{D}: P<0.005$ \\
\hline & 8 & 405 & $10 \cdot 4$ & 405 & $7 \cdot 0$ & 445 & $12 \cdot 6$ & 426 & $9 \cdot 6$ & $\mathrm{~T}: P<0.0001$ \\
\hline & 12 & 389 & $6 \cdot 7$ & 417 & $3 \cdot 8$ & 440 & $7 \cdot 23$ & 436 & $6 \cdot 7$ & $\begin{array}{l}\mathrm{D} \times \mathrm{T}: P<0.05 \\
\mathrm{~W}: \mathrm{NS}\end{array}$ \\
\hline \multicolumn{11}{|c|}{$\begin{array}{l}\text { ITT }(\min \times \mathrm{mmol} / \mathrm{l}) \ddagger \\
\text { Expt } 2 \text { (gestation and lactation diet) }\end{array}$} \\
\hline & 4 & 224 & $12 \cdot 8$ & 257 & $13 \cdot 9$ & 236 & 11.4 & 233 & $11 \cdot 8$ & D: NS \\
\hline & 8 & 226 & $5 \cdot 6$ & 242 & $9 \cdot 0$ & 248 & 9.9 & 262 & $14 \cdot 3$ & $W: P=0.05$ \\
\hline & 12 & 224 & $8 \cdot 5$ & 241 & $13 \cdot 4$ & 233 & $7 \cdot 2$ & 233 & $8 \cdot 5$ & $\begin{array}{l}\mathrm{D} \times \mathrm{W}: \mathrm{NS} \\
\mathrm{T}: \mathrm{NS}\end{array}$ \\
\hline
\end{tabular}

D, dams' diet; C, casein; S, soya protein; W, weaning diet; T, time; GTT, glucose tolerance test; ITT, insulin tolerance test.

${ }^{*}$ MIXED model with $D$ and $W$ as main factors.

† GTT: after overnight fasting, rats received glucose $(0.375 \mathrm{~g}$ glucose $/ \mathrm{ml}, 5 \mathrm{~g}$ glucose $/ \mathrm{kg}$ body weight) by oral administration and blood glucose was measured before and 15 , 30 and 60 min later.

‡ ITT: insulin (Humulin ${ }^{\circledR}$ R; Eli Lilly and Company, Indianapolis, IN, USA) injections were given intraperitoneally (0.5 U/ml, $0.75 \mathrm{U}$ insulin/kg body weight) and blood glucose was measured before and 15, 30 and 60 min later.

(SEM 1.5) v. 18.2 (SEM 1.0) g, $P<0.05$ ) and FPM were also larger in offspring (34.9 (SEM 2.4) v. 30.9 (SEM 1.8) g, $P<0.05)$ born to $\mathrm{S}$ diet-fed dams at week 15 .

There was no effect of protein source in diets fed throughout gestation and lactation on fasting plasma glucose at birth or at weaning in the offspring (Table 5). However, the dams' diet affected glucose metabolism in later life. Fasting BG at week 15 was higher in offspring born to dams on the $\mathrm{S}$ diet $(P<0.005$; Table 3). BG (tAUC) response to the glucose administration was also higher at weeks 4,8 and 12 $(P<0.002)$ in offspring from the $\mathrm{S}$ diet-fed dams. The effect of the dams' diet became stronger with time $(P<0.0001)$ as shown by the interaction $(P<0.05)$ of the dams' diet with time.

The effect of insulin injections (ITT) on BG was not affected by dams' or weaning diets or by time. The source of protein in the dams' diets had no effect on plasma insulin in the fetus at day $20(P=0.08)$ or in the pups at birth $(P=0 \cdot 08$; Table 5$)$. However, at weaning, offspring born to the dams fed the $S$ diet had higher fasting plasma insulin $(50 \%, P<0.05)$, HOMA-IR $(33 \%, P<0.05)$ and homocysteine $(32 \%, P<0.05)$ (Table 5), and at week 15, had higher HOMA-IR (24\%) $(P<0.01$; Table 3$)$. Higher SBP and DBP were found in the offspring born to the $\mathrm{S}$ diet-fed dams at 4,8 and 12 weeks $(P<0.05$; Table 2$)$. This effect of the gestation and lactation diet of the dam interacted with the weaning diet $(P<0.01)$, explained by much higher SBP in pup consuming the $S$ diet and born to mothers fed the $S$ diet. Pulse rate of the offspring was also higher at 4,8 and 12 weeks in the offspring born to dams fed the $\mathrm{S}$ diet $(P<0 \cdot 05)$. Overall, pulse rate decreased with time $(P<0.05$; Table 2$)$. The dams' diet had no effect on fasting plasma corticosterone in the offspring (Tables 3 and 5). The pup diet had no statistically significant effect on any of the parameters measured.
Dams. BW of the dams was not affected by their diet during gestation (Fig. 3). However, BW was higher after parturition (7\%) and at week 1 of lactation (9\%) in dams fed the $\mathrm{C}$ diet $(P<0 \cdot 05)$. Fasting plasma glucose was higher in $\mathrm{S}$ diet-fed dams at day $14(9 \%, P=0.06)$ and at day 20 $(16 \%, P<0.05)$, but not at week 6 after weaning. No dams' diet effects were found in dams' fasting plasma insulin at day 14 or 20 of gestation, but insulin was higher at week 6 in dams fed the $\mathrm{S}$ diet $(21 \%, P<0 \cdot 05)$, as was the HOMA-IR index at day 20 of gestation $(72 \%, P<0.05)$ and week 6 after weaning $(30 \%, P<0.05)$ (Table 6). The diets of the dams did not affect their fasting plasma homocysteine, corticosterone or albumin (Table 6), SBP and DBP at week 2 after weaning (Table 2), GTT and ITT at week 4 after weaning or FPM at days 14 and 20 or week 6 after weaning (data not shown).

\section{Discussion}

The results of these experiments support the hypothesis that nutritionally complete diets differing in protein sources and fed during gestation alone or during gestation and lactation differ in their effects on characteristics of the metabolic syndrome in the offspring. The $\mathrm{S}$ diet, compared with the C-based diet, increased BW, body fat, SBP and DBP, and led to impaired insulin sensitivity and glucose tolerance in the male offspring. However, protein source in the pups' diet had little impact on the primary effects of protein source in the dams' diets on the offspring.

Extending the duration of the test diets from gestation alone in Expt 1 to gestation and lactation in Expt 2 resulted in a more robust effect of the $\mathrm{S}$ diet on BW, body composition and glucose metabolism in the offspring. The $\mathrm{S}$ diet fed during 


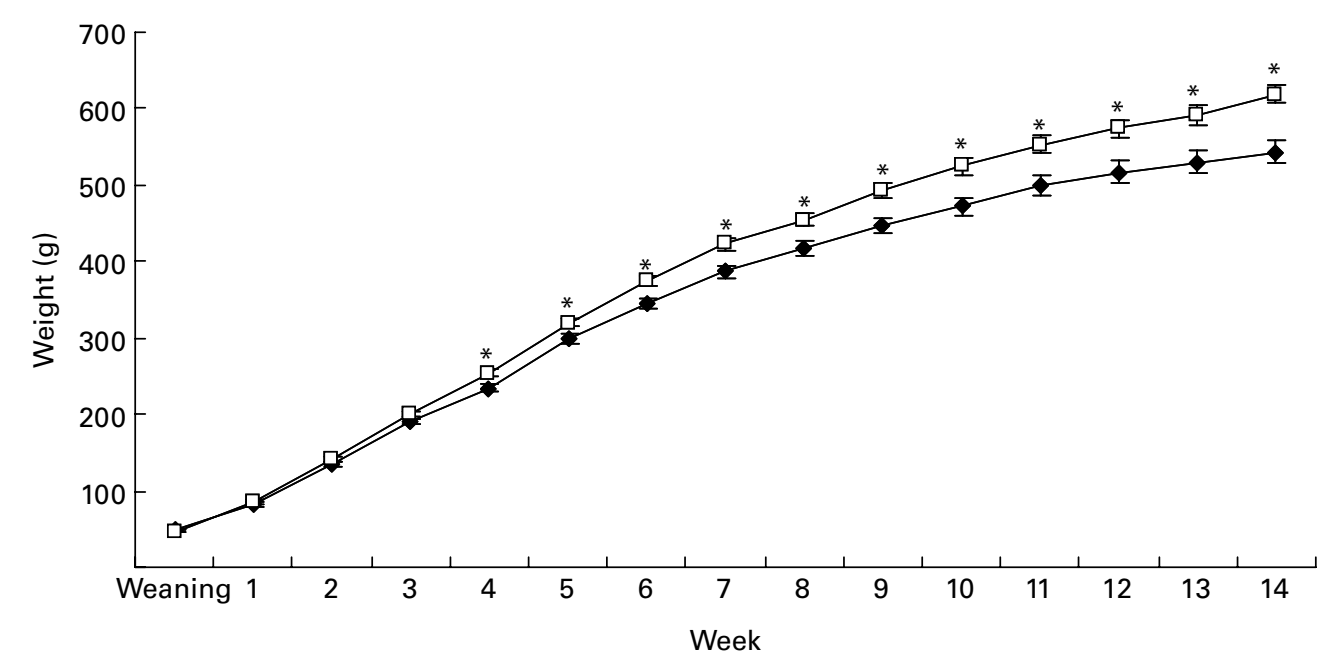

Fig. 2. Expt 2: effect of protein source during gestation and lactation on post-weaning body weight (BW) of male offspring. Values are means, with their standard errors represented by vertical bars $(n 12)$. BW was analysed by MIXED model followed by Tukey's post hoc test with the diets fed during gestation and lactation (dams' diets), weaning diets and time as main factors: gestation and lactation diet $(P<0.05)$; weaning diet (NS), dams' diet $\times$ time $(P<0.01)$. ${ }^{\star}$ Mean values were significantly different $(P<0.05)$. Data are pooled for the pup diet to present the effect of the dams' diet alone on BW. C, casein $(-\checkmark-)$; $\mathrm{S}$, soya protein $(-\square-)$.

gestation and lactation increased BW of the offspring 4 weeks earlier (weeks $4 v$. 8) than when fed only during gestation and also led to impaired glucose metabolism. Furthermore, it was made clear that the increase in BW was due to increased body fat. Thus, protein composition in the diet consumed during lactation also affected development and is consistent with continued development of intake regulatory systems of the hypothalamus and gastrointestinal tract in rodents in late pregnancy and the early postnatal period ${ }^{(19,27)}$

The effects of protein source in diets fed to the dams throughout gestation and lactation were not modified by the composition of diets fed to the pups. This was surprising because the Predictive Adaptive Response Hypothesis is based on the premise that offspring weaned to similar diets as their mothers will adapt more appropriately to their postnatal environment than those receiving an unmatched $\operatorname{diet}^{(28)}$. Clearly, the adverse effect of the $\mathrm{S}$ diet fed to the dams on BP (Table 2) and glucose regulation (Tables 3-5) in the offspring was not diminished by feeding the pups with $\mathrm{S}$ diets.

The more favourable effect of casein on BP (Table 2) may have its origins in both the amino acids and bioactive peptides (BAP) it contains. Casein and soya protein differ in amino acid composition $^{(29)}$ (Table 1). Soya protein contains only half the proline content of casein and may be a factor because the high $\mathrm{BP}$ of offspring born to dams fed low-protein gestational diets is reduced by adding glycine, proline and/or threonine ${ }^{(15,30)}$. Consumption of hydrolysates of proteins lowers $\mathrm{BP}$ in both human subjects and animals ${ }^{(31,32)}$, suggesting that bioactive peptides may be a factor. For example, in hypertensive human subjects, consumption of a daily dose of casein hydrolysate $(0.49 \mathrm{~g} / \mathrm{d})$ containing the peptides valineproline-proline and isoleucine-proline-proline, known to inhibit in vitro angiotensin-converting enzyme, lowered both $\mathrm{SBP}$ and $\mathrm{DBP}^{(33)}$. In hypertensive rats, oral administration of derivatives of casein hydrolysate $(32 \mathrm{mg} / \mathrm{kg} \mathrm{BW}$ per $\mathrm{d}$ ) significantly decreased $\mathrm{BP}^{(32)}$. Based on in vitro measures of angiotensin-converting enzyme activity, bioactive peptides have been found to be more abundant and inhibitory in casein $^{(34)}$ than in soya protein ${ }^{(35,36)}$ but their role in vivo is uncertain because of the low absorption of the active peptides ${ }^{(37)}$. However, casein is also rich in casomorphins capable of activating opioid receptors in the enteric nervous system and on the vagus, resulting in vasodilation ${ }^{(31,34,38)}$.

A weakness of the present study is that the effects observed could be due to a combination of the effects of the proteins and the amino acid additions to the diets. Thus, it cannot be concluded that soya protein alone had adverse effects compared with casein. To provide an adequate diet, as recommended in the AIN 93G diets, both methionine and

Table 5. Expt 2: effect of protein source fed during gestation and lactation on fasting plasma measures in offspring

(Mean values with their standard errors, $n 5-6$ )

\begin{tabular}{|c|c|c|c|c|}
\hline & \multicolumn{4}{|c|}{ Gestation and lactation diet } \\
\hline & \multicolumn{2}{|c|}{$\mathrm{C}$} & \multicolumn{2}{|c|}{$S$} \\
\hline & Mean & SEM & Mean & SEM \\
\hline \multicolumn{5}{|l|}{ Fetus (day 20 of gestation) } \\
\hline Insulin (ng/ml) & 0.28 & 0.03 & 0.41 & $0.06^{*}$ \\
\hline \multicolumn{5}{|l|}{ Birth } \\
\hline Glucose (mm) & $5 \cdot 2$ & 0.2 & $5 \cdot 4$ & 0.3 \\
\hline Insulin (ng/ml) & 0.27 & 0.07 & $0.49^{*}$ & 0.08 \\
\hline HOMA-IR $†$ & 0.06 & 0.01 & $0 \cdot 11$ & 0.02 \\
\hline \multicolumn{5}{|l|}{ Weaning } \\
\hline Glucose (mm) & $5 \cdot 2$ & 0.2 & $5 \cdot 3$ & $0 \cdot 1$ \\
\hline Insulin (ng/ml) & $0 \cdot 12^{\mathrm{a}}$ & 0.01 & $0 \cdot 18^{b}$ & 0.02 \\
\hline HOMA-IR & $0.03^{a}$ & 0.00 & $0.04^{b}$ & 0.00 \\
\hline Corticosterone (ng/ml) & $299 \cdot 2$ & $29 \cdot 2$ & $351 \cdot 7$ & $59 \cdot 7$ \\
\hline Homocysteine $(\mu \mathrm{mol} / \mathrm{l})$ & $5 \cdot 7^{a}$ & 0.2 & $8 \cdot 5^{b}$ & 0.9 \\
\hline
\end{tabular}

C, casein; S, soya protein; HOMA-IR, homeostasis model assessment of insulin resistance.

${ }^{a, b}$ Mean values within a row with unlike superscript letters were significantly different $(P<0.05)$

${ }^{*} P=0.08$; unpaired $t$ test.

† HOMA-IR index was calculated as fasting glucose (mM) multiplied by fasting insulin $(\mathrm{ng} / \mathrm{ml})$ divided by 22.5 . 
be sufficient to classify them as diabetic and unlikely to affect the BW of their offspring at birth.

Many physiological properties of soya protein are attributed to its isoflavone content, specifically genistein ${ }^{(51-55)}$ or interactions between isoflavones and other components in the diet (e.g. amino acids) ${ }^{(56)}$. However, the isoflavone content of soya protein is an unlikely factor in the results obtained as the levels were below that associated with physiological effects. The genistein content of the $\mathrm{S}$ diet was $36 \mu \mathrm{g} / \mathrm{g}$ of the diets, well below that reported $(250 \mu \mathrm{g} / \mathrm{g}$ diet $)$ in the maternal diet to affect epigenetic and phenotypic changes in mice $^{(57)}$. Similarly, the results obtained from the present study cannot be explained by stress responses of the dams or pups, for two reasons. First, there were no differences due to the diet in litter size or birth weight of the offspring, or in BW of dams at arrival, days 14 and 20 of gestation (Fig. 3). Second, no difference was found in fasting corticosterone level in either dams at days 14 and 20 of gestation and week 6 post-weaning or pups at weaning and week 15 (Tables 3, 5 and 6).

In summary, this is the first study to show that nutritionally complete diets based on soya protein or casein and fed to rat dams affect the metabolic phenotype of the offspring. This observation is of particular significance because the majority of animal studies aimed at understanding the effects of maternal diets on development are based on malnutrition models. In contrast, the present study shows that metabolic outcomes in the offspring may differ among 'normal' diets used for maintenance of the dams during pregnancy and lactation. For example, the source of protein in laboratory chow diets is highly variable and often includes herring fish, whey and plant proteins. In addition, there are several recommended AIN-93 diets with various sources of proteins (e.g. casein, soya and whey protein). Clearly, even though judged to be nutritionally complete diets, protein source and many other aspects of test diets fed during pregnancy and lactation in animal models of development could be a factor explaining variance in outcomes among studies.

The relevance of these results to human subjects is uncertain because human diets during gestation contain many mixed protein sources. On the other hand, infants are weaned to formula that are dependent on single sources of proteins or their hydrolysates during early life and may be a factor affecting development of regulatory systems and later life outcomes.

\section{Conclusion}

Soya protein, when compared with casein-based AIN-93G diets and fed during gestation or during gestation and lactation, increased the risk of developing characteristics of the metabolic syndrome in the offspring.

\section{Acknowledgements}

The present study was supported by the Natural Sciences and Engineering Research Council of Canada. The authors thank the management and technicians at the Department of Comparative Medicine at the University of Toronto. All the authors contributed to the preparation of the paper and read and approved the final manuscript. G. H. A. and A. J.-M. conceptualised and designed the research. A. J.-M., P. S. P. H., C. Smith, A. Hamedani and B. L. L. conducted the research. A. J.-M. analysed the data. A. J.-M., G. H. A. and I. M. Y. S. wrote the paper. G. H. A. had the primary responsibility for the final content. The authors declare that there are no conflicts of interest.

\section{References}

1. Barker DJ \& Law CM (1994) Birth weight and blood pressure in adolescence. Studies may be misleading. BMJ 308, 1634 .

2. Adair LS, Kuzawa CW \& Borja J (2001) Maternal energy stores and diet composition during pregnancy program adolescent blood pressure. Circulation 104, 1034-1039.

3. Eriksson R \& Olsson B (2004) Adapting genetic regulatory models by genetic programming. Biosystems 76, 217-227.

4. Langley-Evans SC, Phillips GJ \& Jackson AA (1994) In utero exposure to maternal low protein diets induces hypertension in weanling rats, independently of maternal blood pressure changes. Clin Nutr 13, 319-324.

5. Langley-Evans SC, Gardner DS \& Jackson AA (1996) Maternal protein restriction influences the programming of the rat hypothalamic-pituitary-adrenal axis. J Nutr 126, $1578-1585$.

6. Rees WD, Hay SM, Brown DS, et al. (2000) Maternal protein deficiency causes hypermethylation of DNA in the livers of rat fetuses. J Nutr 130, 1821-1826.

7. Lucas A (2005) The developmental origins of adult health and well-being. Adv Exp Med Biol 569, 13-15.

8. Zambrano E, Bautista CJ, Deas M, et al. (2006) A low maternal protein diet during pregnancy and lactation has sex- and window of exposure-specific effects on offspring growth and food intake, glucose metabolism and serum leptin in the rat. J Physiol 571, 221-230.

9. Langley SC \& Jackson AA (1994) Increased systolic blood pressure in adult rats induced by fetal exposure to maternal low protein diets. Clin Sci (Lond) 86, 217-222, discussion 121.

10. Macedo GS, Ferreira CL, Menegaz A, et al. (2008) Correlation of serum leptin and insulin levels of pregnant proteinrestricted rats with predictive obesity variables. Braz J Med Biol Res 41, 519-525.

11. Desai M, Crowther NJ, Ozanne SE, et al. (1995) Adult glucose and lipid metabolism may be programmed during fetal life. Biochem Soc Trans 23, 331-335.

12. Daenzer M, Ortmann S, Klaus S, et al. (2002) Prenatal high protein exposure decreases energy expenditure and increases adiposity in young rats. J Nutr 132, 142-144.

13. Thone-Reineke C, Kalk P, Dorn M, et al. (2006) High-protein nutrition during pregnancy and lactation programs blood pressure, food efficiency, and body weight of the offspring in a sex-dependent manner. Am J Physiol Regul Integr Comp Physiol 291, R1025-R1030.

14. Langley-Evans SC (2001) Fetal programming of cardiovascular function through exposure to maternal undernutrition. Proc Nutr Soc 60, 505-513.

15. Jackson AA, Dunn RL, Marchand MC, et al. (2002) Increased systolic blood pressure in rats induced by a maternal low-protein diet is reversed by dietary supplementation with glycine. Clin Sci (Lond) 103, 633-639. 
16. Petrie L, Duthie SJ, Rees WD, et al. (2002) Serum concentrations of homocysteine are elevated during early pregnancy in rodent models of fetal programming. $\mathrm{Br} J$ Nutr 88, 471-477.

17. Brawley L, Torrens C, Anthony FW, et al. (2004) Glycine rectifies vascular dysfunction induced by dietary protein imbalance during pregnancy. J Physiol 554, 497-504.

18. Cherif H, Reusens B, Ahn MT, et al. (1998) Effects of taurine on the insulin secretion of rat fetal islets from dams fed a low-protein diet. J Endocrinol 159, 341-348.

19. McMillen IC \& Robinson JS (2005) Developmental origins of the metabolic syndrome: prediction, plasticity, and programming. Physiol Rev 85, 571-633.

20. Jiang Y, Sun T, Xiong J, et al. (2007) Hyperhomocysteinemiamediated DNA hypomethylation and its potential epigenetic role in rats. Acta Biochim Biophys Sin (Shanghai) 39, 657-667.

21. Hietaniemi M, Santaniemi M, Malo E, et al. (2009) Gene expression profiles in fetal and neonatal rat offspring of energy-restricted dams. J Nutrigenet Nutrigenomics 2 , 173-183.

22. Reeves PG, Nielsen FH \& Fahey GC Jr (1993) AIN-93 purified diets for laboratory rodents: final report of the American Institute of Nutrition ad hoc writing committee on the reformulation of the AIN-76A rodent diet. J Nutr 123, 1939-1951.

23. Szeto IM, Aziz A, Das PJ, et al. (2008) High multivitamin intake by Wistar rats during pregnancy results in increased food intake and components of the metabolic syndrome in male offspring. Am J Physiol Regul Integr Comp Physiol 295, R575-R582.

24. Sacco SM, Jiang JM, Reza-Lopez S, et al. (2009) Flaxseed combined with low-dose estrogen therapy preserves bone tissue in ovariectomized rats. Menopause 16, 545-554.

25. Thompson LU, Boucher BA, Cotterchio M, et al. (2007) Dietary phytoestrogens, including isoflavones, lignans, and coumestrol, in nonvitamin, nonmineral supplements commonly consumed by women in Canada. Nutr Cancer 59, $176-184$.

26. Muniyappa R, Lee S, Chen H, et al. (2008) Current approaches for assessing insulin sensitivity and resistance in vivo: advantages, limitations, and appropriate usage. $\mathrm{Am}$ J Physiol Endocrinol Metab 294, E15-E26.

27. Remacle C, Dumortier O, Bol V, et al. (2007) Intrauterine programming of the endocrine pancreas. Diabetes Obes Metab 9, Suppl. 2, 196-209.

28. Gluckman PD \& Hanson MA (2004) The developmental origins of the metabolic syndrome. Trends Endocrinol Metab 15, 183-187.

29. Phillips SM, Tang JE \& Morre DR (2009) The role of milkand soy-based protein in support of muscle protein synthesis and muscle protein accretion in young and elderly persons. J Am Coll Nutr 28, 343-354.

30. Bagley PJ \& Stipanuk MH (1995) Rats fed a low protein diet supplemented with sulfur amino acids have increased cysteine dioxygenase activity and increased taurine production in hepatocytes. J Nutr 125, 933-940.

31. FitzGerald RJ, Murray BA \& Walsh DJ (2004) Hypotensive peptides from milk proteins. J Nutr 134, 980S-988S.

32. Mizuno S, Nishimura S, Matsuura K, et al. (2004) Release of short and proline-rich antihypertensive peptides from casein hydrolysate with an Aspergillus oryzae protease. J Dairy Sci 87, 3183-3188.

33. Nakamura T, Mizutani J, Sasaki K, et al. (2009) Beneficial potential of casein hydrolysate containing Val-Pro-Pro and Ile-Pro-Pro on central blood pressure and hemodynamic index: a preliminary study. J Med Food 12, 1221-1226.
34. FitzGerald RJ \& Meisel H (2000) Milk protein-derived peptide inhibitors of angiotensin-I-converting enzyme. $\mathrm{Br} J$ Nutr 84, Suppl. 1, S33-S37.

35. Meisel H (1993) Casokinins as bioactive peptides in the primary structure of casein. In Food Proteins: Structure and Functionality, pp. 67-75 [KD Schwenke and R Mothes, editors]. Weinheim, NY: VCH.

36. Saito $\mathrm{T}$ (2008) Antihypertensive peptides derived from bovine casein and whey proteins. Adv Exp Med Biol 606, 295-317.

37. Foltz M, van der Pijl PC \& Duchateau GS (2010) Current in vitro testing of bioactive peptides is not valuable. $J$ Nutr 140, 117-118.

38. Meisel H (1997) Biochemical properties of regulatory peptides derived from milk proteins. Biopolymers $\mathbf{4 3}$ $119-128$

39. Steegers-Theunissen RP \& Steegers EA (2003) Nutrient-gene interactions in early pregnancy: a vascular hypothesis. Eur J Obstet Gynecol Reprod Biol 106, 115-117.

40. Hultberg B, Andersson A, Masson P, et al. (1994) Plasma homocysteine and thiol compound fractions after oral administration of N-acetylcysteine. Scand J Clin Lab Invest 54, 417-422.

41. Verhoef P, Steenge GR, Boelsma E, et al. (2004) Dietary serine and cystine attenuate the homocysteine-raising effect of dietary methionine: a randomized crossover trial in humans. Am J Clin Nutr 80, 674-679.

42. Fukada S, Morita T \& Sugiyama K (2008) Effects of various amino acids on methionine-induced hyperhomocysteinemia in rats. Biosci Biotechnol Biochem 72, 1940-1943.

43. Giltay EJ, Hoogeveen EK, Elbers JM, et al. (1998) Insulin resistance is associated with elevated plasma total homocysteine levels in healthy, non-obese subjects. Atherosclerosis 139, 197-198.

44. Fonseca V, Keebler M, Dicker-Brown A, et al. (2002) The effect of troglitazone on plasma homocysteine, hepatic and red blood cell S-adenosyl methionine, and S-adenosyl homocysteine and enzymes in homocysteine metabolism in Zucker rats. Metabolism 51, 783-786.

45. Randeva HS (2003) Hormonal regulation of homocysteine. Metab Syndr Relat Disord 1, 121-128.

46. Dorner G, Plagemann A, Ruckert J, et al. (1988) Teratogenetic maternofoetal transmission and prevention of diabetes susceptibility. Exp Clin Endocrinol 91, 247-258.

47. Aerts L, Holemans K \& Van Assche FA (1990) Maternal diabetes during pregnancy: consequences for the offspring. Diabetes Metab Rev 6, 147-167.

48. Dorner G \& Plagemann A (1994) Perinatal hyperinsulinism as possible predisposing factor for diabetes mellitus, obesity and enhanced cardiovascular risk in later life. Horm Metab Res 26, 213-221.

49. Silverman BL, Rizzo T, Green OC, et al. (1991) Long-term prospective evaluation of offspring of diabetic mothers. Diabetes 40, Suppl. 2, 121-125.

50. Plagemann A, Harder T, Kohlhoff R, et al. (1997) Overweight and obesity in infants of mothers with long-term insulindependent diabetes or gestational diabetes. Int J Obes Relat Metab Disord 21, 451-456.

51. Cassidy A \& Griffin B (1999) Phyto-oestrogens: a potential role in the prevention of CHD? Proc Nutr Soc 58, 193-199.

52. Nagao T, Yoshimura S, Saito Y, et al. (2001) Reproductive effects in male and female rats of neonatal exposure to genistein. Reprod Toxicol 15, 399-411. 
53. Amin H, Holst JJ, Hartmann B, et al. (2008) Functional ontogeny of the proglucagon-derived peptide axis in the premature human neonate. J Pediatr 121, e180-e186.

54. Cotterchio M, Boucher BA, Kreiger N, et al. (2008) Dietary phytoestrogen intake - lignans and isoflavones - and breast cancer risk (Canada). Cancer Causes Control 19, 259-272.

55. Kavanagh K, Jones KL, Zhang L, et al. (2008) High isoflavone soy diet increases insulin secretion without decreasing insulin sensitivity in premenopausal nonhuman primates. Nutr Res 28, 368-376.

56. Noriega-Lopez L, Tovar AR, Gonzalez-Granillo M, et al. (2007) Pancreatic insulin secretion in rats fed a soy protein high fat diet depends on the interaction between the amino acid pattern and isoflavones. J Biol Chem 282, 20657-20666.

57. Dolinoy DC, Weidman JR, Waterland RA, et al. (2006) Maternal genistein alters coat color and protects Avy mouse offspring from obesity by modifying the fetal epigenome. Environ Health Perspect 114, 567-572. 